\title{
全国メニスクス手術例について

$\begin{array}{ccccc}\text { 九州大学医学部整形外科教室 } & \text { 久 } & \text { 米 } & \text { 祥 } & \text { 生 } \\ & \text { 副 } & \text { 島 } & \text { 義 } & \text { 彦 }\end{array}$

\section{On the Operated Cases of Meniscus Injuries in Japan}

By

\section{Y. Kume \& Y. Soejima.}

Department of Orthopedic Surgery, Faculty of Medicine, Kyūshū University

(Direct.: Prof. T. Amako)

先に吾々は，九大整形外科に於ける摘出メニスクス 151 例につき調査し, 外側メニスクス障害が, 内側入 ニスクスのそれに比し, 泽かに高率である事を知り得 たと共に，天览教授の「日本人メニスクスは諸外国の 症例に反し，内側メニスクスが甚だ少ない，等の特異 性を有している」との説を或る程度, 襄付けする事が 出来たが，更に我々は，来年の日本整形外科学会総会 に於ける天児教授の宿題報告の研究の一環として, 日 本全国に亘るメニスクス手術の跛勢を, 全国大学, 官, 公, 市立病院整形外科へ依頼し, 多数の御援助, 御 協力を頂き，相当の結果を得たので，嬑に報告する。

先つ我々が調查依頼した病院は総数 152 病院であり らち 76 病院より御返事を頂く事が出来たが，紙上甚 た恐縮ながら，御多忙中，御協力，御援助，を頂いた 事に対し, 厚く御礼申上げると共に, 深く感謝の意を 表する次第である。

双て，我々が知り得た，全国メニスクス障害者の手 術例数は, 表 1 の如く, 外側メニスクス障害の 857 例 に対し,内側メニスクスのそれは 227 例であり, 内側 対外側のメニスクス障害比は, 1 対 4, となり，「表 $2 」$ に於ける，米，英，独，濠，等の諸外国の統計と は全く異なり，明らかに反対の比率を現はしている。 之をその形態別に分類すると，「表 $3 」$ 」如く，外側 メニスクスの場合は, 正常型 349 例, 異型 351 例, で あり，両者間に大差は認められないが，内側メニスク に於ては，異型は僅かに 15 例を数えるに過ぎない。 又, 正常型のみを対象として, 内, 外のメニスクス障 害例を比較しても，内側の 158 例に対し, 外側の障害 例は 349 例の多きを数觉, 殆んど 2 倍以上の数值を示 している。
以上の事から，我が国に於ては，外側メニスクスの 障害頻度が甚だ高く, 又同恃に，異型メニスクス障害 の頻度も極めて高率である事が判るのである。

表 1 月本人メニスクス手術例数

\begin{tabular}{|c|c|c|}
\hline 部 位 & 例 数 & $\%$ \\
\hline 內側メニスクス & 227 & 20.9 \\
\hline 外側メニスクス & 857 & 79.1 \\
\hline 計 & 1084 & \\
\hline
\end{tabular}

表 2 各國に於りるメニスクス損傷の內外比

\begin{tabular}{|c|r|r|r|c|c|}
\hline & & 外側 & 丙側 & 比 & 計 \\
\hline Smillie & 英 & 534 & 966 & $1: 2$ & 1500 \\
\hline Mac Ausland & 米 & 31 & 357 & $1: 11$ & 388 \\
\hline Andreesen & 独 & 21 & 567 & $1: 27$ & 588 \\
\hline Ahern & 嫁 & 25 & 117 & $1: 5$ & 142 \\
\hline 天 兒 & 日 & 857 & 227 & $4: 1$ & 1084 \\
\hline
\end{tabular}

表 3 內, 外メニスクスの形態別

\begin{tabular}{|c|c|c|c|c|}
\hline & 正常型 & 異 型 & その他 & 計 \\
\hline 內 側 & $\begin{array}{c}158 \\
(69.6)\end{array}$ & $\begin{array}{c}15 \\
(6.6)\end{array}$ & $\begin{array}{c}54 \\
(23.7)\end{array}$ & 227 \\
\hline 外 側 & $\begin{array}{c}349 \\
(40.8)\end{array}$ & $\begin{array}{c}351 \\
(40.9)\end{array}$ & $\begin{array}{c}157 \\
(18.3)\end{array}$ & 857 \\
\hline 計 & $\begin{array}{c}507 \\
(46.8)\end{array}$ & $\begin{array}{c}366 \\
(33.9)\end{array}$ & $\begin{array}{c}211 \\
(19.3)\end{array}$ & 1084 \\
\hline
\end{tabular}


表 4 內，外メニスクス損傷の原因

\begin{tabular}{|c|c|c|c|}
\hline & 特 発 性 & 外傷性 & 計 \\
\hline 内 側 & $\begin{array}{c}63 \\
(22.7)\end{array}$ & $\begin{array}{c}164 \\
(77.3)\end{array}$ & 227 \\
\hline 外 側 & $\begin{array}{c}391 \\
(45.7)\end{array}$ & $\begin{array}{c}465 \\
(54.3)\end{array}$ & 857 \\
\hline 計 & $\begin{array}{c}454 \\
(41.8)\end{array}$ & $\begin{array}{c}630 \\
(58.1)\end{array}$ & 1084 \\
\hline
\end{tabular}

表 5 外側メニスクス損傷原因

\begin{tabular}{|c|c|c|c|}
\hline & 外傷性 & 特発性 & 計 \\
\hline 正常型 & $\begin{array}{c}218 \\
(62.2)\end{array}$ & $\begin{array}{c}131 \\
(37.8)\end{array}$ & 349 \\
\hline 異 型 & $\begin{array}{c}153 \\
(43.5)\end{array}$ & $\begin{array}{c}198 \\
(56.4)\end{array}$ & 351 \\
\hline そ 他 & $\begin{array}{c}95 \\
(60.5)\end{array}$ & $\begin{array}{c}62 \\
(39.4)\end{array}$ & 157 \\
\hline
\end{tabular}

表 6 內側メニスクスの損傷原因

\begin{tabular}{|l|c|c|c|}
\hline & 外傷性 & 特発性 & 計 \\
\hline 正常型 & $\begin{array}{c}129 \\
(76.6)\end{array}$ & $\begin{array}{c}37 \\
(23.4)\end{array}$ & 158 \\
\hline 異 型 & $\begin{array}{c}6 \\
(40.0)\end{array}$ & $\begin{array}{c}9 \\
(60.0)\end{array}$ & 15 \\
\hline その他 & $\begin{array}{c}37 \\
(68.5)\end{array}$ & $\begin{array}{c}17 \\
(31.5)\end{array}$ & 54 \\
\hline
\end{tabular}

表 7 断裂の認められないメニスクス障害の原因

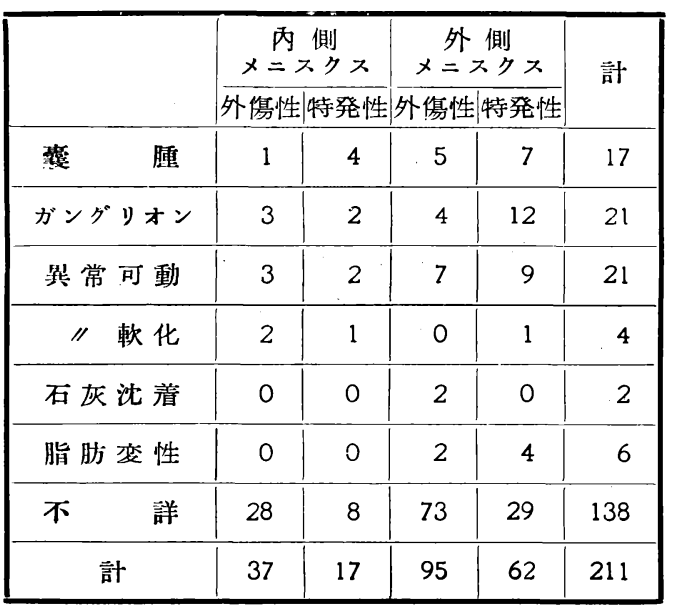

表 8 变形性関節症の発生頻度

\begin{tabular}{|r|c|c|c|}
\hline & 尖銳化 & 䊏堤形成 & 計 \\
\hline 大腿骨下端脛側 & 6 & 1 & 7 \\
\hline "I 腓側 & 4 & 2 & 6 \\
\hline 脛骨上端脛側 & 29 & 3 & 32 \\
\hline " 腓側 & 39 & 21 & 60 \\
\hline 有しないもの & & & 17 \\
\hline
\end{tabular}

表 9 術后に於ける娈形性関節症の游長（38 例）

\begin{tabular}{|c|c|c|c|c|}
\hline & & 術前 & 術后 & 增加数 \\
\hline \multicolumn{2}{|c|}{ 大腿骨下端脛側 尖 鍄 化 } & 5 & 5 & 0 \\
\hline 腓側 & "I & 3 & 4 & 1 \\
\hline 脛骨上端脛側 & "I & 14 & 15 & 1 \\
\hline 腓側 & "I & 16 & 17 & 1 \\
\hline \multicolumn{2}{|c|}{ 大垠骨下端脛偩: 緣堤形成 } & 0 & 0 & 0 \\
\hline 腓側 & "I & 1 & 1 & 0 \\
\hline 脛骨上端 脛側 & "I & 0 & 0 & 0 \\
\hline 腓側 & "I & 10 & 10 & 0 \\
\hline \multicolumn{2}{|c|}{ 变形性関節症なきもの } & 8 & 8 & 0 \\
\hline
\end{tabular}

「表 $4 」$ は, 内外メニスクス障害の摘出例を夫々原因 別に分類した場合であるがが, 内側のメニスクス障害 例に於ては，明らかに原因としての外傷を認められる 例が多く，特発性に由来する場合は 63 例， $(22.7 \%)$ に過ぎないのに反し，外側のそれに於ては，外賃性の 例と特発性の時の例とは殆んぞその差はなく，言い変 えれば，外側メニスクス障害例のうち，その原因とし て外傷を認められない場合が甚だ多いのである。之の 事は日本人の外側メニスクスは, 異型が多く, 為に障 害が起り易いのであると考兄られ，又一方，絶えず滕 の屈伸を余儀なくされる生活環境も又メニスクス障害 の発生に重要な役割を演じているのであらうとも考兄 る事が出来る。

以上の事は, 又内, 外メニスクス障害の摘出例を夫 々，形態別に，その原因を追求する事に依つて一層明 白にする事が出来る。即ち「表 $5 」 「$ 表 6 」に見る様 に，外側メニスクス障害例の場合は，正常型に於ては 
外鹪を原因とする尓が多く，62.2\%を示しているの に対し，異罳に於ては，反対炕特発性に由来する朴の カが多く, 56.4 \%を占めているのである。内側 メ二 スクス障害例の埸合も，外侧の埸合と，罪型に於ては 差はないが，正常堽に於て，外側の場合より，外伤を 原园とするものが，より高率を示している事は注目す ベき事と思はれる。

以上揭げた「表」中「その他」とあつたのは，総て を通信に依つた為，その形態，及その詳細を知り得な からた例を含み，断裂が認められなからた障害例であ

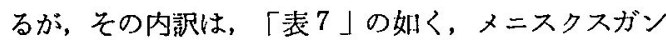
グリオン，異常河動，露腫等が多くみられ，珠に何れ む外側メニスクス障培例に多くなつている。

以上メニスクス站書の手術例について述べたが，尚， 斯くの如く摘出されたメニスクス陾整者の予后につい

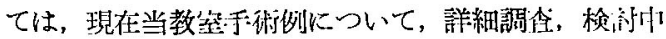
であるが，その一部である「メニスクス摘出術は余り 期待むてない」とされる鼠大の原因として指船される

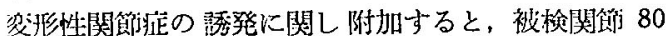
関節，全て外側メニスクス障製の場合であるが，「表 $8 」$ 儿示与如人，既北前，レ線上に於て，その部 位, 程度の如何に関らず，尖鋭化，或は縁提形成等

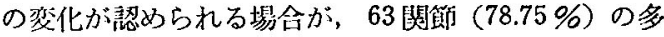
きに達して居り，全く裂化の無い，認めない場合は僅 かに 17 関领に過ぎない。又夜形症として，障㕩側の， 即ち暌霄，上端腓倒の尖鋭化，或は縁提形成が著しく多 い事は，芸だ興味梁い事である。次に之等の変形性関 䬣症の，䍐在迄調榃し得た 38 関節の消長については， 「表 $9 」$ 」如く，術前，全く変化を認めなかつた 8 関 筑は，術后 1 年非以上，5ケ年経過した例症である が，術后む全く変形を生ぜず，疼指も完全に消失して 居る。又術前より，変化を発生していた例では，術前 他の部分に変化のあつたもので，新らたに，異なる部 分へ，変化を生じた例，3例，之の他，眐爱上端排側 の头鋭化の程度が，柽度に増強したと思はれるすの 3

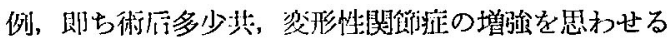
場合は，合部 6 例に邀ぎない。

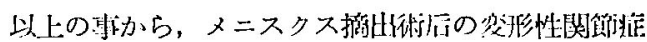

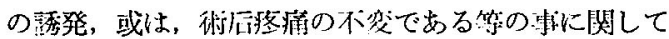

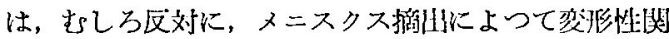

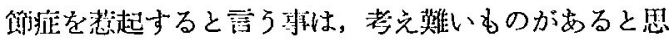

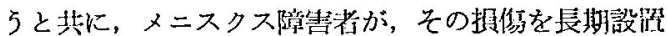
する事低つて発生するのが多いのではないかと考え る事が出来ると思う。
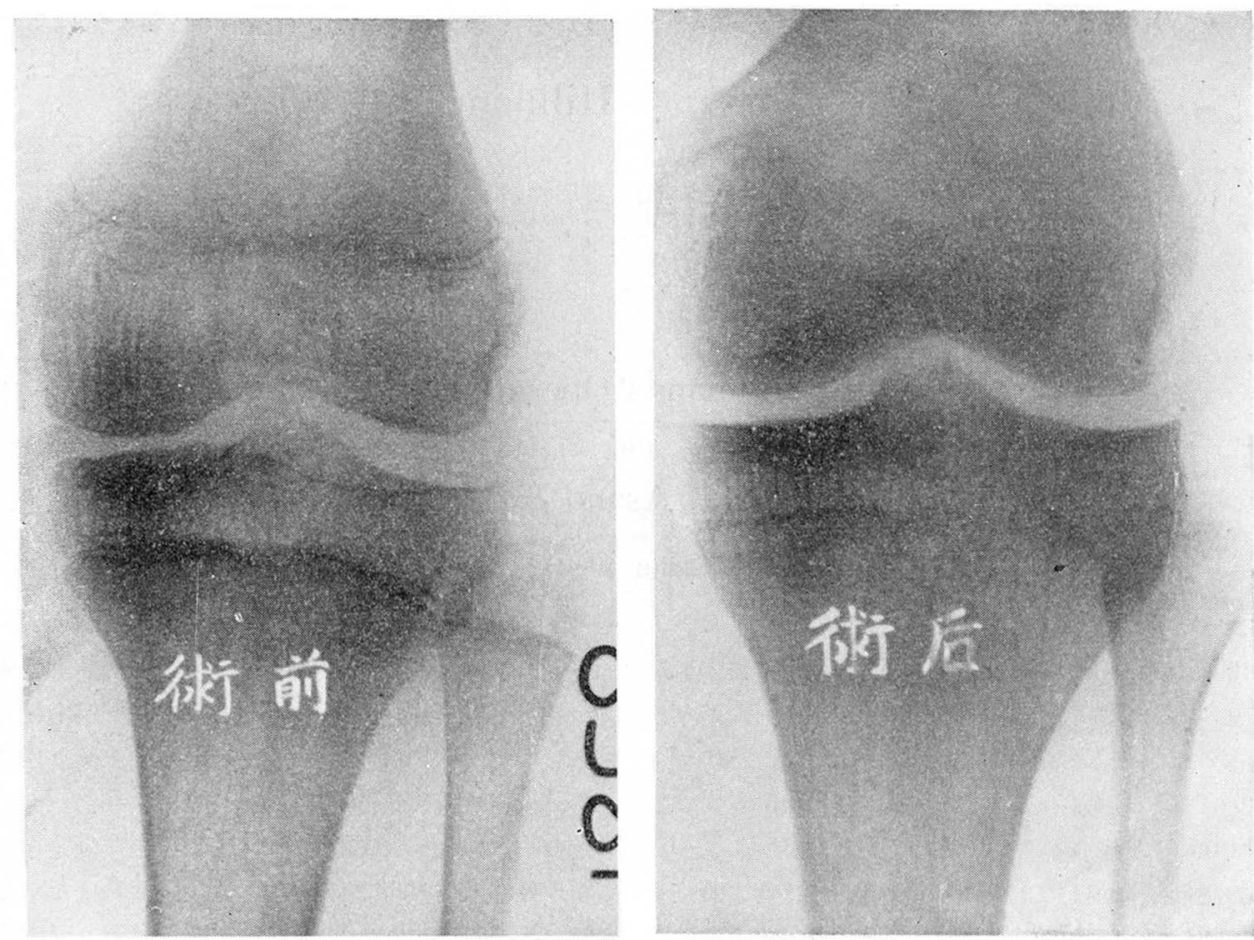

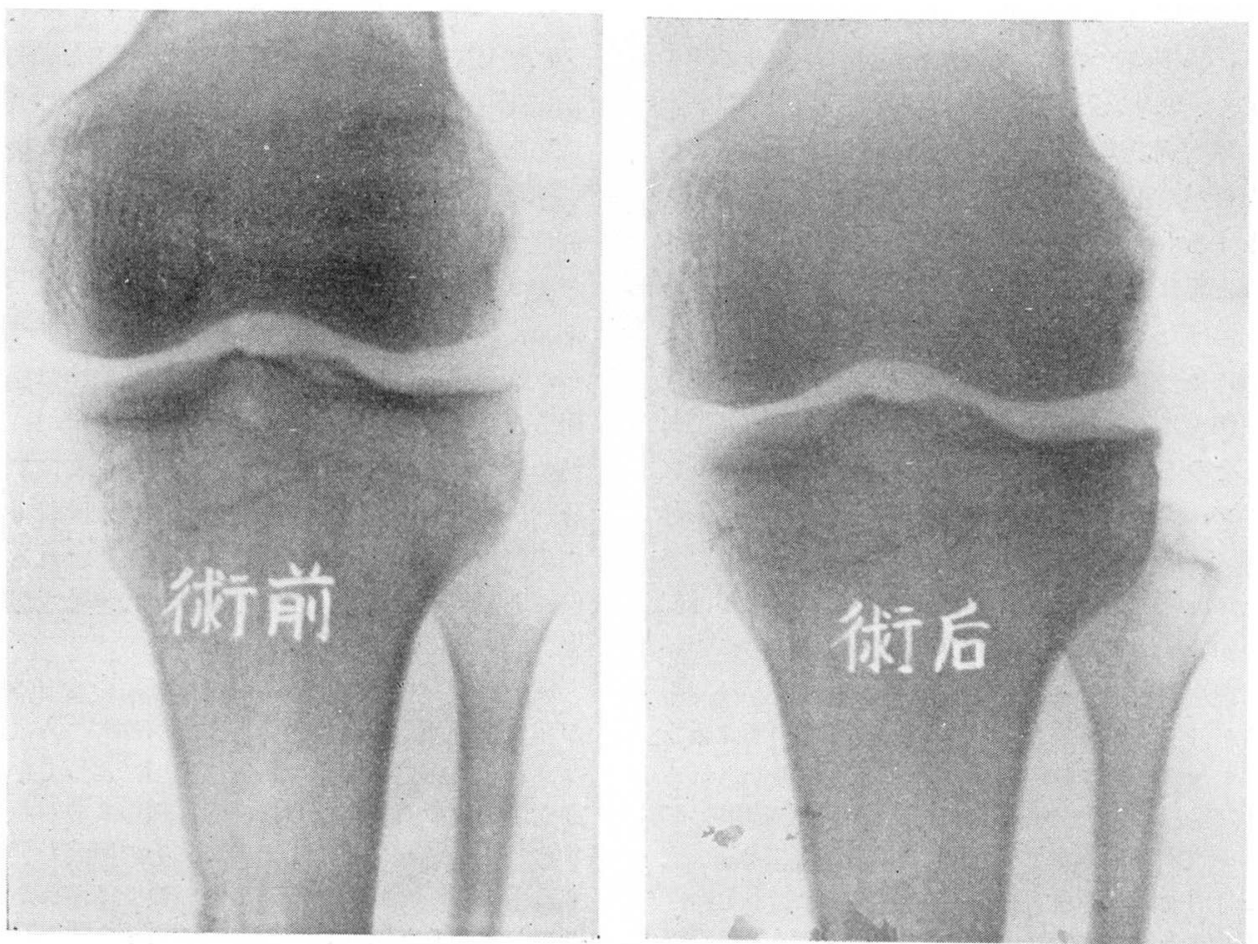

\section{Mallet - Finger に対する Hillmanns 氏手術の経験}

\begin{tabular}{|c|c|c|c|c|}
\hline 九州厚生年金病院 & 整形外科 & 岩 & 永 & \\
\hline & & 浅 & 野 & 冒 \\
\hline & & 的 & 場 & 政 \\
\hline
\end{tabular}

The Experience of Hillmanns' Operation for Mallet-Finger

By

\section{T. Iwanaga M. Asano \& M. Matoba}

Orthopedic Clinic, Ky ūshū Welfare Pension Hospital

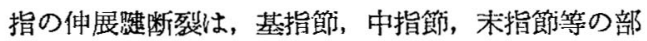
位により，それぞれ特有の変形を呈してくる。なかで も末指節の涏附着部の近くにおける涏断裂は, その頻 度においてもつとも高く，所謂 Mallet-Finger 又は Drop-Finger と呼代るものである。(図 1 参照) この 末指節の煺断裂に対しては各種の治潦法が報告されて いるが，実際やってみると困難な問題に遭遇する。
先つ観血的方法においては，未来指節の伸展涎附着部 が殆んど膜様を呈していること, 又鋼線等を使用する にしても管の口径が小なるため, 技術上屡々困難を伴 い，術後機能障害を残した例が認められた。ついで固 定の方法においても, 解剖学的飞正確な固定指位の問 題，及び 固定期間を比較的永く続けねばならぬため に，その途中に捺いて屡々安定性を欠き，又固定によ 